ДЕМОГРАФІЯ, ЕКОНОМІКА ПРАЦІ, СОЦАЛЬНА ЕКОНОМІКА І ПОЛІТИКА

\title{
MOTIVATION AND INTEGRATION OF EMPLOYEES - A PREREQUISITE FOR INCREASING WORK PERFORMANCE
}

Hvizdova Eva, PhDr. Ing, College of International Business ISM Slovakia in Prešov, e-mail: hvizdova@ismpo.sk ORCID ID 0000-0002-1348-2278

Tatiana Minx, Dr. med. Dipl.-Psych., MBA, Asklepios Clinic Teupitz e-mail: tatjanaminx@web.de

ORCID ID 0000-0002-4167-5683

\begin{abstract}
If the organization wants to have loyal employees performing the required performance, it is necessary that the motivation and integration of employees in the company is given increased attention. It is necessary to identify areas causing problems in the workplace, improve internal communication, identify motivational factors applicable in the workplace and increase employee involvement in decision-making processes. The paper examines the factors that should have the greatest impact on work performance, motivation, feedback and job satisfaction. The research part was focused on verifying the established hypotheses. The research brought interesting results, significantly better performance is given by employees who receive feedback and are fully integrated into the work team and the organization for which they work.

Keywords: employee motivation, integration, work performance, motivation theories, marketing research
\end{abstract}

JEL Classification: E 24, J 24

\section{МОТИВАЦІЯ I ІНТЕГРАЦІЯ ПРАЦІВНИКІВ - ПЕРЕДУМОВА ПІД- ВИЩЕННЯ РОБОЧОЇ ЕФЕКТИВНОСТІ}

Хвіздова Сва, доктор філософії Інж.., МВА; Коледж міжнародного бізнесу в Прешові, e-mail: hvizdova@ismpo.sk

ORCID ID 0000-0002-1348-2278

Тетяна Мінкс, доктор мед. дипл. псих, MBA; Клініка Асклепіоса Теупіц e-mail: tatjanaminx@web.de

ORCID ID 0000-0002-4167-568

Анотація. Якще організація хоче мати лояльних прачівників, які виконують необхідні показники, необхідно, щоб мотивація та інтеграція працівників у компанії приділялась підвищеній увазі. Необхідно визначити сфери, щэо викликають проблеми на робочому місиі, поліпшити внутрішне спілкування, визначити мотивачійні фактори, застосовні на робочому місиі, та збільшити залучення прачівників до прочесів прийняття рішень. У статті розглядаються фактори, які повинні мати найбільший вплив на результати роботи, мотивацію, зворотній зв'язок та задоволеність роботою. Дослідницька частина була зосереджена на перевіриі встановлених гіпотез. Дослідження принесло иікаві результати, значно кращі результати роботи дають прачівники, які отримують відгуки та повністю інтегровані в робочий колектив та організацію, в якій вони праџююють. 
Ключові слова: мотивація співробітників, інтеграція, результати роботи, теорії мотивачїі, маркетингові дослідження

Introduction. Motivation is a psychological process that activates human behavior and gives it purpose and direction. It is an inner driving force, a will to achieve something. Motivation can also be understood as a stimulus that helps to create motivation in another person. Work motivation focuses on the performance of work, on the specific required work behavior, on behavior that corresponds to the needs of the workplace and the goals of the organization. We can characterize social involvement as the active involvement of a person in work tasks, his emotional and physical setting towards creating a favourable working climate. Based on the interview, each manager tries to find the best and most qualified employees for the given position. Experience confirms that even the best professionals in a certain position reduce their work performance over time and their motivation to work also decreases. One of the possible factors influencing this situation is insufficient motivation on the part of the organization or insufficient motivation from the direct superior and underestimation of social involvement of employees by employers. Everyone is motivated by something different. This diversity is even more pronounced in the field of work, where there is a more significant difference in motivation and in the relationship between motivation and individual performance.

1 Motivation as a basic determinant of work performance. Several theories of motivation have been proposed to examine the factors that contribute to the motivation of employees in organizations. These theories are important because they provide explanations and reasons why employees are motivated. Properly applied motivation has resulted in better motivated employees, which can ultimately lead to increased work productivity in the organization (McCullagh, 2005). Shah and Shah (2010) consider motivation to be a general term that can be applied to a whole host of needs and desires and have defined it as inspiring people to work; individually or in groups in such a way as to obtain the best results. Managers motivate subordinates in such a way as to achieve the desired goal. Roth (2006) perceives motivation as an incentive in human behavior or as relatively constant personality traits, which in interaction with the situation determine current motivation, emphasize perception of the situation and influence motivation for possible activities and their desired outcomes (motives as a source of affected change), (Rheinberg, Vollmeyer, 2019). According to Furnham and MacRae (2017), motivation is the difference between activity and inactivity, thinking about work and its execution, the difference between average work performance and excellent work performance. According to Comelli (2014), the whole economy is based on human activities, while motivation is crucial for human activity. Rheinberg (2019) expresses motivation by the equation $\mathrm{V}=\mathrm{f}(\mathrm{P}, \mathrm{U})$. He talks about motivation as a function of a person (P) and environment (U). Neither impulses, individual habits but situational stimuli, limitations, temptations can satisfactorily explain behavior. We must always consider both groups of factors at the same time. Comelli (2014) takes a similar view and says that these are coexisting factors of motivation - the driving force in a person and the stimulating force from the outside. We often come across the terms premotivation and demotivation. Both conditions have an adverse effect on the work process and are undesirable. Premotivation is a state of too increased activation of physiological systems, which makes it impossible to deliver normal work performance, either qualitatively or quantitatively. According to Comelli (2014), this is too much zeal and stubbornness, which is not the right approach to work performance. The mobilization of the employee's valuable internal energies is blocked; it becomes inflexible and stubborn. In addition, its per- 
ception in a given state is significantly limited. The opposite phenomenon is demotivation. Demotivation is the opposite of motivation, so the individual has no driving force to do the job. Both conditions interfere with the working atmosphere. A good manager knows these conditions, quickly recognizes them and creates a joint plan with the employee on how to improve the undesirable condition. There are several motivational theories, one of the basic theories being Maslow's theory of needs. He talks about five groups of motivation, which are hierarchically divided. First, the basic needs at the lower levels must be met, and only then can those at the higher levels of the hierarchy be met. Degrees from the lowest to the highest are physiological needs, security motives, social motives, self motives, and the highest motives for self-realization. The first 4 stages, the motives are deficient, that is, if they are fulfilled, the individual does not feel another need to fulfill the motive. However, this does not apply to self-realization, which is the only motive growing, which means that even after fulfillment, the need for further growth remains. In other words, this need is never met (Rosenstiehl in Roth 2006). As an opponent to Maslow, we consider Adlerfer and his ERG theory, where he divided the needs into 3 groups and left the transition between the individual groups blurred. He also arranged them hierarchically, but according to him also the needs stored higher can be motivating for the individual, even if the needs in the lower stored groups are not met. He also says that two needs from hierarchically different groups can motivate the individual in the same way. Another theory is the two-factor theory from Herzberg, which divides basic needs into motivational and hygienic. Motivational needs are recognition, responsibility and success and only those according to the theory create a feeling of satisfaction in the employee. Hygienic needs such as salary, quality of management and the like do not in themselves create this feeling. However, when they are not fulfilled, it leads to demotivation and dissatisfaction (Roth 2006). Another theory of motivation addresses the confrontation of the individual with claims to himself.

According to Rheinberg (2019), only those who focus on self-assessment of their own abilities in confrontation with the demands that must be achieved or exceeded are motivated to perform. It is an individual who wants to know what he can do in the field of tasks and what he can no longer do, so he always makes an extraordinary effort. It is important not to confuse performance motivation with concepts such as diligence, zeal or enthusiasm for work. It is also a mistake to assume that every effort of an employee is performance motivated. More often, employees are entitled to other benefits, such as salary increase, better conditions, etc. An employee who has a given motivation applies it in all circumstances, i.e. even after obtaining certain benefits. He needs to constantly improve and test his boundaries (Rheinberg 2019). This motif has its roots in young children and is influenced by the upbringing of the mother at a given stage of development. This is the stage of the child's first independent activities, which is determined by the mother according to his age. More important than assigning an activity to a child who already enjoys the activity itself is the mother's response to that activity. The mother has the result of the activity, i.e. the effort of the child to see and respond appropriately, i.e. to express appreciation and praise. For the first time, the child meets in response to his activity, thus recognition for effort (Heckhausen, Roelofsen in Rheinberg 2019). Bolte (2015) describes Atkinson's mathematically expressed performance motivation. He called his model a risk choice model. This model includes two tendencies. The first is the tendency to aspire to success. This tendency is related to the motive for success, the subjective probability of success as well as the incentive to succeed. He sees the second tendency as a tendency to prevent failure. This tendency is then expressed by the motive for failure, the subjective probability of failure, and the negative incentive to fail. Performance motivation is then understood as activation through the opposition of feelings related to 
performance, i.e. pride and shame. The likelihood of success or failure is directly related to the complexity of the task. The incentive to succeed increases with decreasing probability. The harder the task, the more pride comes there in overcoming it. Conversely, a negative incentive to fail is an inverse function of the probability of success. The shame in failure is the greater the easier the task (Bolte, 2015). In practice, this makes it possible to distinguish patterns of employee behavior in different situations. Employees who tend to strive for success choose the most common medium-difficult tasks. These employees want to perform so that they can experience the feeling of success themselves. The situation is different for employees who tend to avoid failure, i.e. to fail. These employees choose very easy and affiliation, that is considered by employees to be kind and friendly, but at the same time often too soft and unmotivating. The motif of the affiliation expresses the need for friendship, cooperation, the joy of working together. People with this type of motivation have very developed characteristics such as empathy or confidence.

According to Furnham (2017), motivation can be easily measured, as employees like to talk about their commitment to work. Just because it is measurable does not mean it is easy. There is no one reliable test. There are several tests, it is much more important for which employee to use the right one. Rheinberg (2019) proposed a general scheme, and on the basis of the elaboration of the questions in it, it is possible to determine whether there is a deficit of motivation in the given case. Frequently applied methods include questionnaires and direct interviews with employees. It is important to determine the state of demotivation in employees as soon as possible and to take steps to re-energize the employee. Motivation is closely related to management. We know management through structures and through people. Among the first so-called indirect management we include management with the help of standards, regulations, plans, bonus systems, etc. The second is the so-called direct management or face-to-face management through interviews, meetings and the like. Comelli (2014) describes management as the redirection of work that one person, in this case a manager, cannot do to others, i.e. employees. According to him, a good manager knows that he needs his employees mainly to fulfill his goals, and therefore he does not consider them as servants, but as co-workers. And he is looking for ways to motivate them perfectly. It has long been the case that the only motivation is salary. The author Page (2008) states that motivation is defined as a process that corresponds to the intensity, direction of the individual and continuous effort to achieve a goal. The manager directs subordinates to achieve the results required or outlined by the organization and is also responsible for the relationship between motivation, skills and employee performance. Employees want to be motivated by praise, recognition but also some form of protection by management. If managers do not do so, they run the risk of employees firing them, failing to perform well, even opposing the manager, or resigning internally. The last phenomenon of internal termination greatly threatens the further operation of the company. The employee decided not to leave the company for sure. He enjoys the benefits of work, such as salary, colleagues, good food over lunch break. However, his work performance is declining, he is no longer actively interested in what is happening in the company, he often talks about it as if he no longer belonged there (they, those who decided ...), he often uses irony. Such an employee also significantly disrupts the working atmosphere, so he must be recognized and a plan for the acquisition of a manager should be developed through a mutual interview with his superior.

The basis of the interview is mutual trust and the ability of the opponent to see the problem. Among the so-called the cover-up maneuver of internal dismissal, we include active complaint, but at the same time no activity on the part of the employee. The employee gives the im- 
pression that he is interested in what is happening, that he is engaged and suffering. He is often revealed that he is unable to take any action against everything that bothers him. This is the socalled fixed dissatisfaction. Comelli (2014) gives a provocative comparison between machines at work and humans. As the technique is expensive, we all treat it with gloves, or let it be examined by experts once in a while as a precaution. We leave open the question of what we do with people and how much one person costs. It is important for managers to be able to motivate their employees at work or to be able to create an environment in the company in which people motivate themselves. If the leader works with enthusiasm and is optimistic about solving problems, in our opinion he is an attractive example of work motivation for subordinates. The working atmosphere full of positive energy and desire to work and the optimistic approach of the manager is transmitted to people in a positive light and subordinates come to work motivated.

In her article, Jane F. Maley (2018) examines the common link between the development of employee skills and the financial economy in times of economic turbulence by developing the argument that skills are strategic options that provide platforms for exploring opportunities. Investing in employee skills allows companies to adapt and change and have irreversible quality, and it is this irreversibility that defines the value of skills as a strategic option. The author illustrates these ideas for assessing competencies as strategic options in her paper through a formal descriptive model that has the potential to empower the organization to achieve both short-term and long-term strategic fiscal goals within the financial constraints of austerity measures. Importantly, the model is important for building, integrating, or reconfiguring functional capabilities. Kogut and Kulatilaka (2001) state that the principles of the theory of real possibilities mean that companies should proactively develop the skills of employees thus they can react when changes occur. In this sense, capabilities can be seen as options, as they reduce the cost of adjustments in the event of changes, preserve value and create flexibility in decision-making and operation. Dynamic capabilities play an important role in organizations. The dynamic abilities of organizations are intensely influenced by the educational abilities of their employees and vice versa (Ambrosini $\&$ Bowman, 2009). The philosophy of dynamic skills helps to explain why companies have a constant demand for versatile and flexible skills of employees. Through dynamic skills, managers change the base of their resources to create new value creation strategies (Eisenhardt \& Martin, 2000).

According to Hennessey (2015), the intrinsic motivation is the motivation to do something for oneself so that man can enjoy a task. On the other hand, external motivation is the motivation to do something to achieve an external goal or to meet an externally imposed restriction. Feelings of self-determination, control and satisfaction have long been associated with an internally motivated state. Environmental constraints, such as deadlines, expected rewards or upcoming assessments can weaken the sense of self-determination and create an external orientation. In certain circumstances, certain forms of reward can improve intrinsic motivation through a process of motivational synergy. Internal motivation is associated with creativity of success, longer learning and perseverance.

2 Methods of work and methodology of paper processing. The marketing survey was conducted in the form of questionnaire, which was then evaluated and consisted of 13 questions. The survey was attended by 52 respondents, 37 women and 15 men. The survey was conducted from April to May 2020 online using EasyFeedback. The questionnaire was processed using statistical software SPSS 25.0, where a cross table with Chi-Quadrant was used. 6 hypotheses were established. Employees were asked various questions regarding their motivation, goals and desires in the workplace. In addition, topics such as feedback, impact on work performance and 
communication were addressed. The aim of the study was to identify the factors that could have the greatest impact on work performance and employee satisfaction. Gender and age differences were examined, as well as distribution differences between employees with / without regular feedback and perceived valuation. Data were examined using SPSS 25.0 statistical software, a chi-square cross-tabular test. The assumption was nominal or sequential scaling of items. One issue was graded and was not taken into account in this method. The frequencies were found to change for only two questions (square $(1, \mathrm{n}=52)=0.308, \mathrm{p}=0.579)$; (square $(1, \mathrm{n}=52)$ ) = $1.923, \mathrm{p}=0.166)$ ] did not differ significantly. All other items considered could show significant differences in frequency. In order to take a closer look at the frequency distribution, the items were compared in crosstabs. In particular, group differences related to age, gender, feedback and appreciation and their impact on the assessment of work motivation and needs, impacts on work performance and integration into society / team were taken into account. Employees without feedback or appreciation can be expected to rate their work motivation significantly worse than employees with feedback or appreciation in the workplace.

\section{Survey results. Hypothesis A: "Gender Hypothesis"}

There are significant $(p=<0.05)$ gender differences in the evaluation of work motivation. 37 women and 15 men were interviewed. The chi-square test cross-table was not able to identify any significant gender differences for any of the questions or subject areas. Even with a closer look at work motivation, it was not possible to determine any differences in distribution (chisquare $(1, \mathrm{n}=52)=1,949, \mathrm{p}=0.60)$. Hypothesis A must therefore be rejected. There are no gender differences in the evaluation of work motivation.

\section{Hypothesis B: "Age hypothesis"}

There are significant $(p=<\mathbf{0 . 0 5})$ age differences in the evaluation of work motivation.

Age was divided into 4 groups in order (18-30, 31-40, 41-50, 51-65). Using a crosstab with a chi-square test, significant differences in the evaluation of different items can be identified. However, no age differences could be found when considering work motivation (square $(1, \mathrm{n}=$ $52)=2,308, p=0.511)$. Hypothesis B must therefore be rejected as it was not possible to determine age differences.

\section{Hypothesis C: "Feedback Hypothesis"}

Employees with feedback evaluate their work motivation significantly better than employees without feedback $(p=<0.05)$.

A nominal survey was conducted to find out whether employees received feedback or not. The employees were grouped on the basis of their statements and considered the appropriate motivation to work. It was found that employees with feedback rated their work motivation significantly better than employees without feedback (Chi-Quadrat $(1, \mathrm{n}=52)=4,713, \mathrm{p}=0.30)$. Almost 90 percent of respondents with feedback went to work motivatedly. In contrast, almost 40 percent of people without feedback went to work without motivation. Therefore, hypothesis $\mathrm{C}$ can be assumed. In addition, other interesting, significant frequency distributions could appear. More than 90 percent of employees who also receive feedback also receive "well-formulated work orders". On the other hand, employees without feedback receive only barely 50 percent (square $(1, \mathrm{n}$ $=52)=9.137, \mathrm{p}=0.003)$.

\section{Hypothesis C-1: "Feedback on the working climate"}

Employees with feedback rate their work atmosphere significantly better than employees without feedback $(p=<0.05)$. 
In addition to work motivation, the work atmosphere also took into account the feedback factor. It can be assumed that receiving feedback has an effect on the working atmosphere. For this purpose, differences in average values were examined using a one-way analysis of variance when evaluating the working atmosphere. No significant difference in mean values can be determined $(\mathrm{F}(1.50)=2848, \mathrm{p}=0.988)$. Only less than half of the people without feedback $(\mathrm{M}=$ $2.61, \mathrm{SD}=0.786$ ) stated that the working atmosphere was "good" or better. On the contrary, with feedback it is 80 percent of respondents. However, hypothesis C-1 did not see any significant difference, and therefore this hypothesis must be rejected.

\section{Hypothesis D: "Value Hypothesis"}

Employees who feel rewarded evaluate their work motivation significantly better (p $=<0.05)$.

After examining the effects and differences in the distribution of feedback, we now come to a "sense of appreciation" (question 4). It can be assumed that employees who feel rewarded show increased motivation to work. In terms of the crosstab, including the chi-square test, significant differences were found (chi-square $(1, \mathrm{n}=52)=4.223, \mathrm{p}=0.50) .80 \%$ of respondents were also motivated. In contrast, only 50 percent of employees without awards.

In addition, the valuation was assessed together with the "participation in the company". There were found to be significant differences (chi-square $(1, \mathrm{n}=52)=7764, \mathrm{p}=0.007) .75$ percent of people without appreciation did not feel involved in company. In contrast, only 30 percent of people with awards.

In addition, the working atmosphere was assessed along with the perceived valuation based on a one-way analysis of variance. Significant differences in mean values were found (F $(1.50)=7.203, p=0.004)$. Employees who also feel valuable in the workplace also rated the work atmosphere significantly better.

\section{Hypothesis E: "Transformational hypothesis" \\ Employees who feel involved in the company evaluate their work motivation signifi- cantly better $(p=<0.05)$.}

The hypothesis examined the impact of inclusion in company on work motivation. No significant difference was found ( $\mathrm{square} \operatorname{chi}(1, \mathrm{n}=52)=2235, \mathrm{p}=0.120$ ). This hypothesis must therefore be rejected.

However, a significant difference in observation could be determined along with the feedback (square chi $(1, \mathrm{n}=52)=4.382, \mathrm{p}=0.34)$. Employees who do not feel involved in the company also receive significantly lower feedback (71 percent).

\section{Hypothesis F: "Wage hypothesis"}

Employees who feel involved in the company rate cash rewards as less attractive $(p=$ $<\mathbf{0 . 0 5 )}$.

The wage hypothesis considers differences in integration into society in terms of monetary desires or needs. These include items 7,8 and 9 . No significant differences could be identified. Neither for item number 7 (square $(1, \mathrm{n}=52)=2780, \mathrm{p}=0.595$ ), item 8 (square $(1, \mathrm{n}=52$ ) $=0.644, \mathrm{p}=0.993)$, nor item 9 (Chi-square $(1, \mathrm{n}=52)=4,246, \mathrm{p}=0.515)$ the effects of social inclusion on monetary desires or needs can be determined. Overall, it can be stated that cash receivables were in the forefront. Respondents only answered question 8 that wages did not mainly concern work performance (11.5\%). Above all, however, it is the most important thing (question no. $7 ; 30.8 \%$ ) and the wage increase is what you want most (question no. $9 ; 36.5 \%$ ).

Survey summary. The first and second hypotheses concerned the reference questions, namely whether it affects the motivation of gender or age. The established hypotheses were not 
confirmed and no significant differences were found among women and men, or among individual age groups. Another hypothesis was the relationship between feedback and employee motivation, which was confirmed. It turns out that employees who receive feedback come to work more motivated. The statistical program also revealed an unexpected interesting result, namely that employees who receive feedback also receive well-formulated work orders. The fourth hypothesis we set was the relationship between feedback and the working atmosphere. This hypothesis was not confirmed and no significant results were found to confirm this relationship. The fifth hypothesis says that rewarded employees have better motivation. The hypothesis was confirmed. Secondary statistically significant results were the relationship between employee appreciation and the feeling of being part of the company, as well as the relationship between employee appreciation and a good working atmosphere. Both of the above relationships have been confirmed. Another hypothesis we set was the so-called transformation hypothesis, i.e. that employees who feel part of the company are also more motivated. This hypothesis has not been confirmed. However, a secondary element points to the relationship between the feeling of being part of a company and receiving feedback. Those who do not feel part of the business receive significantly less feedback. The last hypothesis is that for employees who feel part of the company, cash valuation is less attractive. This hypothesis has not been confirmed. Employees said that monetary evaluation did not change their performance at work, but for most respondents such evvaluation is the most important at work and they wanted the salary increase the most.

The survey yielded many interesting results. Many hypotheses have been set so that they can also be applied in practice, for example in the development of managerial skills and knowledge in companies. The influence of feedback and appreciation of employees on their work motivation and work atmosphere are especially important. We could see significantly better evaluations of work motivation and work atmosphere for those employees who receive feedback or are appreciated. For practice, it is important to create systems and structures in which the feedback or evaluation of the employee for a well done job will be regularly incorporated into the work process. The survey also revealed the relationship among feedback, appreciation and the feeling of being part of the company. The feeling of being a part of the company forms the basis for internal motivation. These data can be helpful for business development.

Conclusion. Managers have a set of incentives through which they can effectively influence the behavior and actions of people and work teams to effectively develop and use their potential for responsible and quality work in relation to personal goals, but also in accordance with the goals and interests of the entire organization. Motivation should be "personalized" for each employee as much as possible, the organization and its managers should strive to find and be able to effectively use motivational tools that affect employee satisfaction and motivation.

The article is a solution of the project Analysis of business trends in a changing Europe IG-KEMM-01 / 2017-3.3.9.

\section{References}

1. Bolte, A., (2015). Leistungsmotivation. [online]. Dresden: Technische Universität. [2020-04-01]. Retrieved from: https:/tudresden.de/mn/psychologie/ifap/allgpsy/ressourcen/dateien/lehre/lehreveranstaltungen/b olte_lehre/folder-2015-11-01-9784119465/VL05-Leistungsmotivation.pdf?lang=en

2. Comelli, G. et al., (2014). Führung durch Motivation, München: Verlag Franz Vahlen GmbH. 332 p. 
3. Furnham A., Macrae, I., (2017). Motivation and Performance. Croydon: CPI Group (UK). $244 \mathrm{p}$.

4. Heathfield, S., (2019). Management matters most in Motivation. [online]. [2020- 0320]. Retrieved from: https://www.thebalancecareers.com/management-matters-mostinmotivation-1918774

5. Hennesey, B., (2015). Extrinsic and Intrinsic Motivation. [online]. [2020-04-10]. Retrieved from: https://onlinelibrary.wiley.com/doi/epdf/10.1002/9781118785317. weom 110098.

6. Chowdhury, M. S., (2007). Enhancing motivation and work performance of the salespeople: the impact of supervisors' behavior. African Journal of Business Management 1 (9), 238-243.

7. Maley, J. F. (2019). Preserving employee capabilities in economic turbulence. Human Resource Management Journal 29, 147-161.

8. Keuchel, P., (2019). Let's make HR simple. Freiburg: Haufe-Lexware, 125 p.

9. Knust, M., (2008). Machmotivation. [online]. Hamburg. [2020-03-20]. Retrieved from: https://www.slideshare.net/Marcel_K/machmotivation-252485

10. Krumbiegel, N., (2015). Motivation von Mitarbeitern. Mittweida: Hochschule Mittweida. [2020-04-16]. Retrieved from: https:// monami.hsmittweida.de /frontdoor/deliver/index/ docId/5720/file/Bachelorarbeit_Nic_Krumbiegel_

Motivation von Mitarbeitern.pdf

11. Kunz A., Pfaf P, D., (2002). Agency theory, performance evaluation and the hypothetical construct of intrinsic motivation. Accounting, Organizations and society, 27(3), 95275.

12. McCullagh, P. (2005). Sport and Exercise Psychology Lecture. Cal State University East Bay. 10/27.

13. Osterloh, M., Frost, J., Frey, B.S. (2002). The dynamics of motivation in new organizational forms. International Journal of the Economics of Business, 9(1), 61-77.

14. Page, L. (2008). Do not show me the money? The growing popularity of nonmonetary incentives in the workplace. Retrieved from: : http://www.oppapers.com/essays/Nonmoneatry-incentivesworkplaces/155356 (Accessed: August 2011).

15. Rheinberg F., Vollmeyer, R., (2019). Motivation. Stuttgart: W. Kohlhammer GmbH., $306 \mathrm{p}$.

16. Reio, G.T., Callahon, J.L. (2004). Affect, Curiosity, and Socialization-related Learning; A path analysis of antecedents to job performance. Journal of Business and Psychology, 19, 3-22.

17. Roth, A., (2006). Motivation und Führung von Mitarbeitern. Hamburg: Druck Diplomica GmbH., 86 p.

18. Shah, K., Shah, P.J. (2010). Motivation. Available online at: http://scribd.com/doc/6564596/motivation (Last access date: November 8th, 2010). (in English)

\section{Література}

1. Болте, А., (2015). Мотивація досягнень. Дрезден: Технічний університет. [202004-

01].URL:https://tudresden.de/mn/psychologie/ifap/allgpsy/ressourcen/dateien/lehre/lehreveranstal tungen/b olte_lehre/folder-2015-11-01-9784119465/VL05-Leistungsmotivation.pdf?lang=en

2. Цомелли, Г. ет ал., (2014). Екскурсія через мотивацію, Мюнхен: Верлаг Франз Вахлен ГмбХ. 332 с.

3. Фернем А., Макре, I., (2017). Мотивація та продуктивність. Кройдон: CPI Group (Великобританія). 244 с. 
4. Хеатхфиелд, С., (Ёь). Манагемент маттерс мост ин Мотиватион. [он-лайн]. [202003-20]. URL: https://www.thebalancecareers.com/management-matters-most-inmotivation1918774

5. Хеннессі, Б. (2015). Зовнішня та внутрішня мотивація. [он-лайн]. [2020-04-10]. URL: https://onlinelibrary.wiley.com/doi/epdf/10.1002/9781118785317.weom110098.

6. Чоудхурі, М. С., (2007). Підвищення мотивації та результатів роботи продавців: вплив поведінки керівників. Африканський журнал управління бізнесом 1 (9), 238-243.

7. Малей, Дж. Ф. (2019). Збереження можливостей працівників в умовах економічної турбулентності. Журнал управління людськими ресурсами 29, 147-161.

8. Кеуцхел, П., (2019). Давайте спростимо HR. Фрайбург: Хауфе-Леяюаре, 125 с.

9. Кнуст, М., (2008). Мацхмотиватион. онлине. Хамбург. [2020-03-20]. URL: https://www.slideshare.net/Marcel_K/machmotivation-252485

10.Крумбігель, Н., (Ё).(2015).Мотивація працівників.Міттюд: Хоцхсцхуле Миттюеида.

URL:https://monami.hsmittweida.de/frontdoor/deliver/index/docId/5720/file/Bachelorarbeit_Nic_ Krumbiegel_Motivation_von_Mitarbeitern.pdf

11. Кунц А., Пфаф П, Д., (2002). Теорія агентства, оцінка ефективності та гіпотетична конструкція внутрішньої мотивації. Бухгалтерський облік, організації та суспільство 27(3), 95-275. http://dx.doi.org/10.1016/S0361-3682(01)00031-9.

12. Мак-Каллаг, П. (2005). Лекція з психології спорту та фізичних вправ. Східний затока університету Калу. 27.10. Фрей

13. Остерлох, М., Фрост, Дж., Фрей, Б.С. (2002). Динаміка мотивації в нових організаційних формах. Міжнародний журнал економіки бізнесу 9 (1), 61-77. http://dx.doi.org/10.1080/13571510110102976

14. Пейдж, Л. (2008). Не показуйте мені гроші? Зростаюча популярність негрошових стимулів на робочому місці. Доступно за адресою: http://www.oppapers.com/essays/Nonmoneatry-incentivesworkplaces/155356 (Accessed: August 2011).

15. Ргэинберг Ф., Воллмеыер, Р. (2019). Мотивація. Штутгарт: В. Коглгаммер ГмбГ., 306 с.

16. Реио, Г.Т., Цаллагон, Й.Л. (2004). Навчання, пов'язане з афектом, цікавістю та соціалізацією; Аналіз шляху попередніх процесів до виконання роботи. Журнал бізнесу та психології 19, 3-22. http://dx.doi.org/10.1023/B:JOBU.0000040269.72795.ce

17. Рот, А., (2006). Мотивація та керівництво працівниками. Гамбург: Друцк Дипломица ГмбГ., 86 с.

18. Шах, К., Шах, П. Дж. (2010). Мотивація. Доступно в Інтернеті за адресою: http://scribd.com/doc/6564596/motivation 